\title{
Wnt signaling in Xenopus embryos inhibits Bmp4 expression and activates neural development
}

\author{
Julie C. Baker, ${ }^{1}$ Rosa S.P. Beddington, ${ }^{2}$ and Richard M. Harland ${ }^{1,3}$ \\ ${ }^{1}$ Department of Molecular and Cell Biology, University of California, Berkeley, California 94720 USA; ${ }^{2}$ Division \\ of Mammalian Development, Medical Research Council National Institute for Medical Research, London NW71AA UK
}

\begin{abstract}
We report a new role for Wnt signaling in the vertebrate embryo: the induction of neural tissue from ectoderm. Early expression of mouse wnt8, Xwnt8, $\beta$-catenin, or dominant-negative GSK3 induces the expression of neural-specific markers and inhibits the expression of Bmp4 in Xenopus ectoderm. We show that Wnt8, but not the BMP antagonist Noggin, can inhibit Bmp4 expression at early gastrula stages. Furthermore, inhibition of $\beta$-catenin activity in the neural ectoderm of whole embryos by a truncated TCF results in a decrease in neural development. Therefore, we suggest that a cleavage-stage Wnt signal normally contributes to an early repression of $B m p 4$ on the dorsal side of the embryo and sensitizes the ectoderm to respond to neural inducing signals from the organizer. The Wnt targets Xnr3 and siamois have been shown previously to have neuralizing activity when overexpressed. However, antagonists of Wnt signaling, dnXwnt8 and Nxfrz8, inhibit Wnt-mediated Xnr3 and siamois induction, but not neural induction, suggesting an alternative mechanism for Bmp repression and neuralization. Conversely, dnTCF blocks both Wnt-mediated $X n r 3$ and neural induction, suggesting that both pathways require this transcription factor.
\end{abstract}

[Key Words: Wnts; neural induction; Bmp4; $\beta$-catenin; Nieuwkoop; mouse]

Received May 14, 1999; revised version accepted October 12, 1999.

Genetic, embryological, and biochemical approaches have led to the identification of Wnt signaling components and the elucidation of a conserved pathway by which Wnt ligands transduce signals. Frizzled molecules, which are seven-pass transmembrane receptors, can bind secreted Wnts (Bhanot et al. 1996; Yang-Snyder et al. 1996). This ligand-receptor interaction activates the cytoplasmic protein Dishevelled, which in turn can repress constitutively active glycogen synthase kinase 3 (GSK3) (Siegfried et al. 1992; Yanagawa et al. 1995). GSK3 activity leads to the phosphorylation of $\beta$-catenin, which is then targeted for proteolysis (Yost et al. 1996). In the absence of GSK3, $\beta$-catenin forms complexes with LEF/TCF DNA-binding proteins and activates downstream targets, some of which, like Xnr3 and siamois, are direct targets (Brannon et al. 1997; McKendry et al. 1997). Modifiers or repressors of Wnt signaling have also been identified including Frzb-1, a secreted inhibitory factor, and the tumor suppressor, APC (Leyns et al. 1997; Vleminckx et al. 1997; Wang et al. 1997).

In Xenopus embryos, overexpression of several Wnt ligands and their signaling components on the ventral side of the embryo results in axis duplication. In this context, Wnts are believed to mimic an early-acting veg-

${ }^{3}$ Corresponding author.

E-MAIL harland@socrates.berkeley.edu; FAX (510) 643-1729. etal dorsalizing center, or Nieuwkoop center. Indeed, Nieuwkoop activities within the embryo appear to be mediated by endogenous Wnt signaling, as depletion of maternal supplies of $\beta$-catenin mRNA suppresses formation of dorsal tissues (Heasman et al. 1994). Consistent with this, $\beta$-catenin protein accumulates in the nuclei on the dorsal side of the embryo where it persists through gastrula stages (Schneider et al. 1996; Larabell et al. 1997; Rowning et al. 1997). Although $\beta$-catenin is required, reagents which block Wnt8 and Dishevelled activities, including the Wnt antagonist Frzb and a dominant-negative Dishevelled, do not prevent normal axis formation. Thus, $\beta$-catenin-dependent intracellular events, possibly mediated by cytosolic inhibitors of GSK3 activity (Yost et al. 1998), may obviate the need for extracellular signaling (Hoppler et al. 1996; Sokol 1996; Leyns et al. 1997; Wang et al. 1997).

Although $\beta$-catenin is essential for the formation of dorsal cell types, Wnt signal transduction has not been implicated in the induction of neural tissue. Neural tissue forms during gastrulation when zygotic signals from Spemann's Organizer antagonize bone morphogenic protein (BMP) signaling in the overlying dorsal ectoderm (Harland 1997). Several BMP antagonists are expressed in Spemann's Organizer and contribute to both dorsal mesodermal and neural identities; these include Noggin (Smith and Harland 1992; Lamb et al. 1993; Smith et al. 
1993; Zimmerman et al. 1996), Chordin (Sasai et al. 1994, 1995; Piccolo et al. 1996), follistatin (HemmatiBrivanlou et al. 1994; Fainsod et al. 1997), Xnr3 (Smith et al. 1995; Hansen et al. 1997), and Cerberus (Bouwmeester et al. 1996; Hsu et al. 1998).

Whereas neural induction in Xenopus is relatively well described, little is known about signals that mediate neural induction in other vertebrates. In other species, structures homologous to the organizer express BMP antagonists, however BMP antagonists do not have potent neural inducing activity in the chick epiblast (Streit et al. 1998), raising the possibility that additional or alternative mechanisms are used for neural induction. To screen for alternative neural-inducing activities, we are identifying molecules from mouse gastrula cDNA libraries that can instruct Xenopus ectoderm to become neural tissue. Using this approach, we cloned a truncated form of $\beta$-catenin that potently neuralizes ectoderm. We subsequently found that mouse Wnt3 (mWnt3) and mouse Wnt8 ( $\mathrm{mWnt} 8$ ) are robust neuralizing molecules. These results are surprising, as several reports have documented that neither Wnt ligands nor their signal transduction components induce neural tissue from naive ectoderm. One exception is a report that Dishevelled has weak neuralizing activity (Sokol et al. 1995).

Because our conclusions differ from previous ones, we have used a variety of methods to demonstrate that Wnts can induce neural tissue. First, in an unbiased screen for neuralizing molecules, we identified a truncated form of $\beta$-catenin. Secondly, we have used several secreted Wnts and their signal transduction components, including Xwnt8, Xwnt3a, mWnt8, mWnt3, Xdsh, dnGSK3, Xfrz8, and $m \Delta \beta$-catenin, and have shown all of these components induce neural tissue in Xenopus ectoderm. Finally, we have used both RT-PCR and in situ hybridization as assays for neural induction.

Because neural induction often results from the inhibition of BMP4 signaling, we tested whether Wnt signaling might attenuate BMP signals in the gastrula. We also tested whether the transcriptional targets of TCF $/ \beta$ catenin complexes are required for Wnt-mediated neural induction. Such targets include Siamois and Xnr3 (Brannon et al. 1997; McKendry et al. 1997), which have been shown to have neural-inducing activity when expressed in ectoderm (Carnac et al. 1996; Hansen et al. 1997). The expression of these targets could be selectively suppressed by dominant-negative forms of Frizzled8 (Deardorff et al. 1998) and Wnt8 (Hoppler et al. 1996), but neural induction still occurs. In contrast, the dominantnegative form of TCF (dnTCF; Molenaar et al. 1996) inhibits neural induction by Wnt8. These results suggest more than one mechanism by which Wnt signaling can induce neural tissue.

\section{Results}

$\mathrm{m} \Delta \beta$-catenin, $\mathrm{mWnt} 8$, and $\mathrm{mWnt} 3$ induce neural tissue

To understand the molecular basis of cellular differen- tiation events occurring in the mouse gastrula, we have constructed early [embryonic day 6.5 (e6.5)] and late (e7.5) mouse gastrula cDNA libraries in an RNA expression plasmid. A total of 50 pools from these libraries each containing 200 bacterial colonies was screened as described previously (Baker and Harland 1996). Synthetic mRNA was injected into the animal hemisphere of onecell Xenopus embryos. At blastula stage, the ectoderm was explanted and allowed to develop to neurula stage (stage 20). The injected ectoderm was then analyzed by RT-PCR for the expression of the pan-neural marker NCAM. One positive pool was sib-selected and the active cDNA was identified as a truncated form of $\beta$-catenin lacking the first 531 nucleotides or 177 amino acids ( $\Delta \beta$-catenin). Previous work has shown that aminoterminal truncations result in stabilization of $\beta$-catenin, likely because of the removal of the proteasome recognition site (Yost et al. 1996; Willert and Nusse 1998; Maniatis 1999).

Although secreted Wnt molecules and $\beta$-catenin are known to play critical roles in the formation of the early body plan, they have not been strongly implicated in the induction of neural tissue. We identified the Wnt ligands, $m W n t 3$ and $m W n t 8$, in a separate assay using the Wnt-responsive gene, $X n r 3$, as a marker. Therefore, we compared the ability of mWnt3, mWnt8, and $\mathrm{m} \Delta \beta$ catenin to induce neural tissue in Xenopus ectoderm. mRNAs were injected into the animal hemisphere of the one-cell Xenopus embryo at concentrations of either 500 pg or $100 \mathrm{pg}$. Ectoderm was removed at blastula stage and cultured until late-neurula (20) (Fig. 1A) or gastrula (10.5) (Fig. 1B) stages. At either concentration, Wnt signaling components convert ectoderm to neural tissue without a mesodermal intermediary, as judged by RT-PCR for NCAM and the muscle-specific marker, muscle actin. Even though all Wnt signaling components tested can induce neural tissue from ectoderm, the extent of Krox20 expression is sensitive to concentration of injected mRNA. In agreement with previous results, ectoderm injected with 1 ng of $m W n t 3, X w n t 3 a, X w n t 8, m W n t 8$, and $m \Delta \beta$-catenin express the Wnt-inducible $X n r 3$ gene at gastrula stages (Fig. 1B). As a control, 1 ng of Xenopus Wnt5a was injected. Xwnt5a represents a different class of Wnt proteins that do not induce axial structures and do not induce Xnr3 expression (Moon et al. 1993). None of these molecules induce mesoderm at the gastrula stage as shown by the absence of Xbra expression (Fig. 1B).

Further evidence that Wnt signal transduction can activate neural development comes from experiments using the Frizzled receptors, $h f z 5$ and $X f z 8$. Although neither $h f z 5$ nor $X w n t 5 a$ can induce ectopic axes in Xenopus embryos, coexpression of Xwnt5a and $h f z 5$ leads to ectopic axial development (He et al. 1997). Yet another Frizzled receptor, $X f z 8$, induces axial development even in the absence of any Wnt ligand (Deardorff et al. 1998). Figure 1C shows that the combination of Xwnt5a (1 ng) and $h f z 5$ ( $1 \mathrm{ng}$ ) induces neural tissue from ectoderm, whereas each component alone is weak or inactive in inducing neural markers. Furthermore, $X f z 8$ (1 ng) in- 

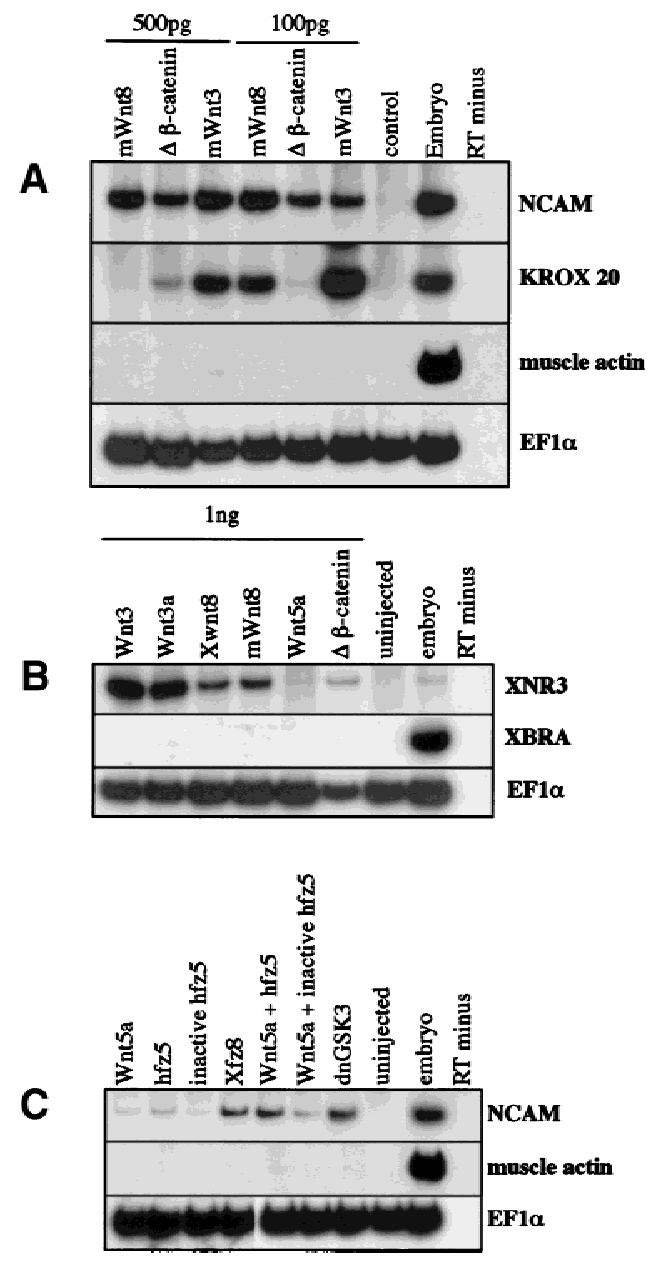

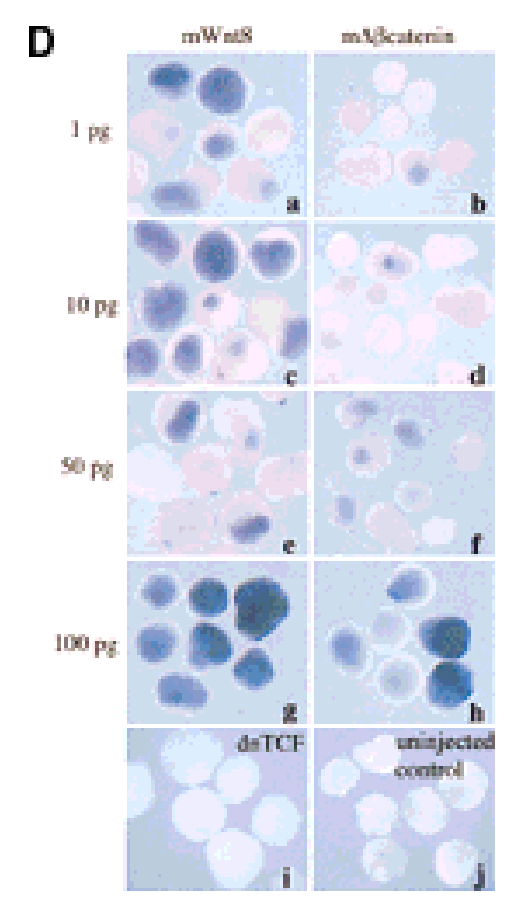

Wnts block Bmp4 and induce neural tissue

Figure 1. Wnt ligands, Frizzled receptors, and signaling components induce neural tissue in Xenopus ectodermal explants. Either mWnt3, Xwnt3a, Xwnt8, $m W n t 8$, or $m \Delta \beta$-catenin $(500$ pg or 100 pg) were injected into one-cell Xenopus embryos. Ectoderm was removed at blastula stage, and RNA extracted at late neurula stage $(20)(A, C)$ gastrula stage (10.5) (B) or for analysis by RT-PCR. (A) Injected ectoderm analyzed at neurula stage for expression of the general neural marker, NCAM, the hindbrain marker, krox-20, the muscle-specific marker, muscle actin, and the ubiquitously expressed internal control, EF1 $\alpha$. (B) Injected ectoderm analyzed at the gastrula stage for the expression of the Wnt inducible gene, $X n r 3$, the general mesodermal marker, Xbra, and EF1 $\alpha .(C)$ Ectoderm injected with $1 \mathrm{ng}$ each of the following: Xwnt5a; human frizzled 5 (hfz5), a mutant human frizzled 5; Xenopus frizzled 8 (Xfz8); dnGSK3; and combinations of Xwnt5a, with either the wild-type hfz5 or mutant hfz5. In $A-C$, RNA from noninjected ectoderm, from whole embryos treated with reverse transcriptase, and from whole embryos treated without reverse transcriptase were used as controls. ( $D$ ) Ectoderm injected with $1,10,50$, or $100 \mathrm{pg}$ of either mWnt8 $(a, c, e, g)$ or $\mathrm{m} \Delta \beta$-catenin $(b, d, f, h)$ aged until stage 20 and analyzed by in situ hybridization for Nrp1. Controls in this experiment include ectoderm injected with $1 \mathrm{ng}$ of $\operatorname{dnTCF}(i)$ and uninjected ectoderm $(j)$. duces neural tissue without the addition of ligand. A negative control in this experiment was an inactive form of $h f z 5$, which results from a point mutation (J. Xie and F. McCormick, pers. comm.) and a positive control was a dominant negative GSK3 (dnGSK3), which lacks kinase activity and mimics the suppression of GSK3 during normal Wnt signaling (Dominguez et al. 1995; He et al. 1995; Pierce and Kimelman 1995).

Because the above experiments were performed using large doses of Wnt signaling components, we titrated the amounts of mRNA used for both $m W n t 8$ and $m \Delta \beta$ catenin. Figure $1 \mathrm{D}$ shows that $m W n t 8$ strongly converts ectoderm into neural tissue even at the low dose of $1 \mathrm{pg}$ (a). Mouse $\Delta \beta$-catenin is capable of inducing neural tissue at $50 \mathrm{pg}$ throughout the ectoderm (f) but is less effective at lower doses $(\mathrm{b}, \mathrm{d})$.

\section{Wht signal transduction molecules induce neural tissue}

To address whether other Wnt signaling components can neuralize, we compared the ability of $m W n t 8, X w n t 8$, $X d s h$ (data not shown), dominant-negative GSK3
(dnGSK3), $m \Delta \beta$-catenin, and dominant-negative $X w n t 8$ (dnXwnt8) to induce neural tissue in ectoderm. dnXwnt8 lacks the carboxy-terminal 98 amino acids and suppresses the axis inducing properties of Xwnt $8, W n t-1$, or Xwnt3a (Hoppler et al. 1996). Ectodermal explants were prepared as described above and double stained at stage 20 by in situ hybridization for the cement gland marker, $X A G-1$ (in red), and the general neural marker, nrp1 (in blue) (Fig. 2B-G), or stained by in situ hybridization for the hindbrain marker, krox-20 (blue) (Fig. 2I-N). The results in Figure 2 demonstrate that all Wnt signal transduction components, including $m \Delta \beta$-catenin, dnGSK3, $d n X w n t 8, m W n t 8$, or Xwnt8 can induce general neural tissue. However, the type of neural tissue, whether anterior or posterior, depends on the reagent used. Ectoderm injected with the Wnt signal transduction components (m $\Delta \beta$-catenin, $d n G S K 3, X d s h)$ induced the anterior cement gland marker $X A G$ and the more posterior neural marker krox-20. The Wnt ligands (mWnt8 and Xwnt8), on the other hand, induced krox-20, but not $X A G$, consistent with the caudalizing activity described by McGrew et al. $(1995,1997)$. In contrast to the wildtype Wnt 8 and as previously shown by Glinka et al. 


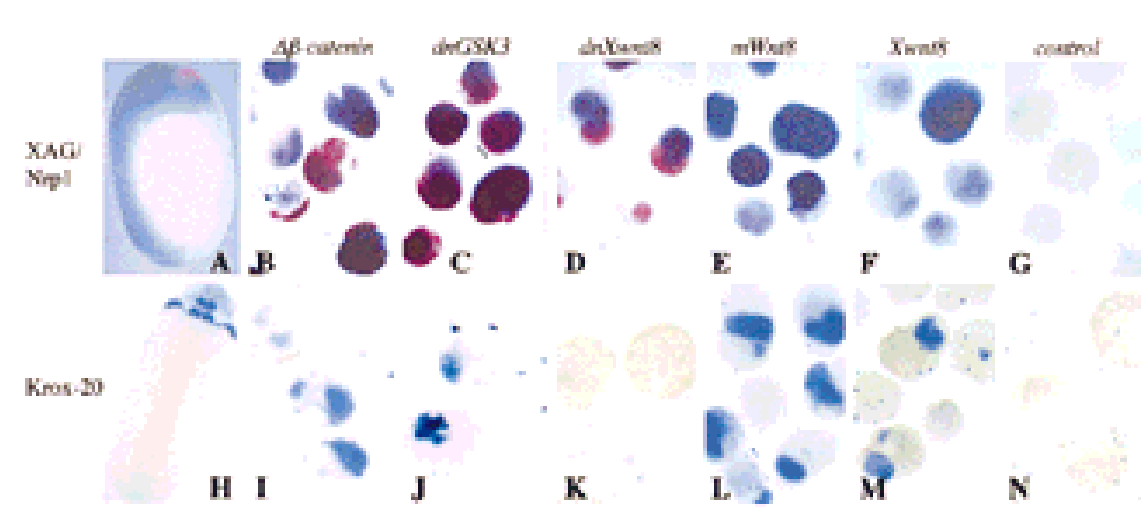

Figure 2. The secreted Wnt ligands Xwnt8 and $\mathrm{mWnt} 8$ induce neural tissue of posterior character, whereas Wnt signal transduction components induce neural tissue of both anterior and posterior character. Onecell Xenopus embryos were injected into the animal hemisphere with $0.5 \mathrm{ng}$ of $\mathrm{m \Delta} \beta$ catenin $(B, I), 1 \mathrm{ng}$ of $d n G S K 3(C, J), 1 \mathrm{ng}$ of $d n X w n t 8(D, K), 0.5 \mathrm{ng}$ of $m W n t 8(E, L)$, and $0.5 \mathrm{ng}$ of $X w n t 8(F, M)$. At blastula stage ectoderm was explanted and allowed to develop until late-neurula stage (20). Aged ectoderm and whole embryos were then double stained by in situ hybridization for the cement gland marker, XAG (red), and the general neural marker, Nrp1 (blue) $(A-$ $G)$ or single stained by in situ hybridization for the hindbrain marker, krox-20 (blue) (H$N)$. $A$ and $H$ are whole-embryo controls; $G$ and $N$ are uninjected ectodermal explants.
(1997), it appears that $d n X w n t 8$ retains the ability to induce anterior neural tissue but lacks the ability to function as a caudalizing agent. However, $d n X w n t$ only functions to induce anterior neural tissue at high concentrations (1 ng or more, data not shown) and therefore has lost most of the neuralizing ability of the wild-type Wnt8. Not only do these experiments show that all of the active signaling components induce neural tissue, but they also show that the efficiency of caudalization is different for different components, with the extreme case being $d n W n t 8$, which only induces anterior tissues.

To dissect whether neural induction by Wnt signaling is the result of an early pathway or a later zygotic pathway, we examined the effect of Wnt expression at various times during development. Introduction of Wnt mRNA into the Xenopus embryo mimics a "Nieuwkoop center," which acts during cleavage and blastula stages to dorsalize the embryo. If Wnt signaling is activated after mid-blastula transition (MBT) (by use of DNA injections), it induces a distinctly opposite response, which is to partially ventralize the embryo (Christian and Moon 1993). Therefore, we injected Wnt constructs under the control of the zygotically active cytomegalovlrus (CMV) promoter. DNA encoding $\mathrm{mWnt} 8$ or mWnt3 was injected at concentrations of 500 pg or 200 pg into Xenopus ectoderm, as described above, and failed to induce neural tissue (data not shown) as assayed by in situ hybridization for Nrp1. Therefore, the ability of Wnts to induce neural tissue is likely to be the result of activation of an early pathway.

\section{Wnt signaling inhibits Bmp4 expression}

To test whether neuralization in Wnt-expressing ectoderm might be mediated by the suppression of BMP4 signaling, we assayed wnt-injected ectoderm for Bmp4 expression. Bmp4 normally initiates expression throughout the embryo, but expression is extinguished on the dorsal side during gastrulation (Fig. 3E) (Fainsod et al.
1994; Hemmati-Brivanlou and Thomsen 1995). Ectodermal explants were stained for $B m p 4$ transcripts at the gastrula stage (10.5) after injection of mWnt8 (0.5 ng), $m \Delta \beta$-catenin $(0.5 \mathrm{ng})$, the Wnt antagonist Frzb (1ng) (Leyns et al. 1997; Wang et al. 1997) (Fig. 3A-D), dsh (1 ng) (data not shown), and dngsk3 (1 ng) (data not shown). Explants were also analyzed for Nrp1 (Fig. 3F-I) and muscle actin (Fig. 3K-M) expression at neurula stage (20). Although the Wnt antagonist, Frzb, has no effect on the ectoderm, all of the Wnt signaling components suppressed Bmp4 expression and converted the ectoderm to neural tissue in the absence of muscle.

Next, we tested whether a constitutively active BMP4 receptor, activated ALK3 (Hsu et al. 1998), could suppress neural fates in the presence of Wnt signaling. Activated $A L K 3$ was expressed in combination with either

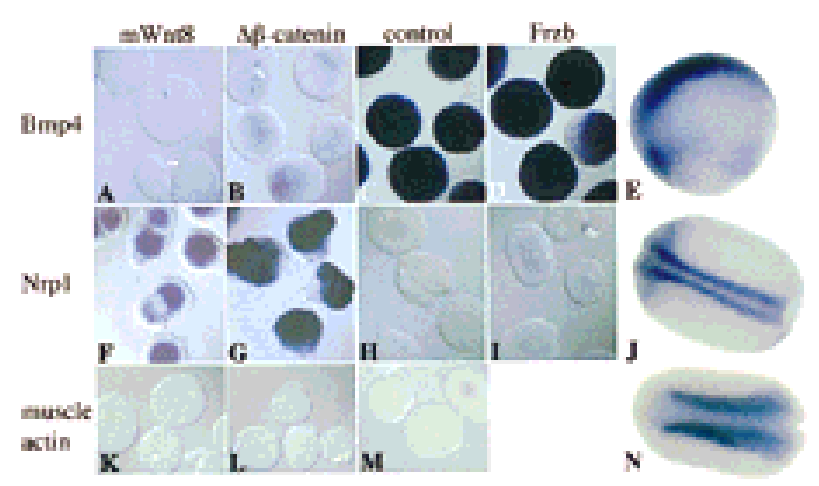

Figure 3. Wnt signaling in ectoderm inhibits the expression of Bmp4. One-cell Xenopus embryos were injected into the animal hemisphere with $0.5 \mathrm{ng}$ of $m W n t 8(A, F, K), 0.5 \mathrm{ng}$ of $m \Delta \beta$ catenin $(B, G, L)$, and $1 \mathrm{ng}$ of $\operatorname{Frzb}(D, I)$. At blastula stage ectoderm was explanted and aged until gastrula stage (10.5) or neurula stage (20). Ectoderm was subsequently probed with digoxigenin-labeled antisense-Bmp4 $(A-D), \operatorname{Nrp1}(F-I)$, or muscle actin $(K-M)$, by in situ hybridization. $E, I$, and $N$ are whole embryos probed with Bmp4, Nrp1, and muscle actin, respectively. $C, H$, and $M$ are uninjected control ectodermal explants. 
$m \Delta \beta$-catenin or $m W n t 8$ in Xenopus ectoderm. Activation of BMP4 signaling by ALK3 prevented the Wnt-mediated suppression of Bmp4 expression (data not shown) and prevented neuralization of ectoderm (Fig. 4). We therefore suggest that in normal development both Wnt and BMP pathways affect the expression of $B m p 4$ and the ultimate fate of the ectoderm.

Wnt8, but not noggin, blocks BMP4 expression during gastrulation

The expression of $\mathrm{Bmp} 4$ is lost during gastrulation only on the dorsal side of the embryo, which is poised to become the neural plate. The extinction of BMP4 from this prospective neural tissue has been hypothesized to be due to secreted signals from Spemann's organizer, which block BMP4 from associating with its cognate receptors. This failure of BMP4 signaling would then lead to the repression of Bmp4 expression, as BMPs have been shown to positively regulate their own expression at neurula stage in Xenopus and during gastrulation in zebrafish (Jones et al. 1992; Hammerschmidt et al. 1996; Piccolo et al. 1997; Nguyen et al. 1998). However, because Wnt signaling can inhibit Bmp4 expression in ectoderm and because it is well documented that $\beta$-catenin is expressed in the nucleus of the dorsal cell types at gastrulation, we wanted to determine whether early Wnt signaling, not secreted organizer signals, might be responsible for the extinction of $B m p 4$ expression on the dorsal side of the embryo. Therefore, ectoderm expressing either $250 \mathrm{pg}$ mWnt 8 or 100 pg noggin was harvested at early and late gastrula stages $(10,10.5$, and 12) and stained for Bmp4 transcripts by in situ hybridization (Fig. 5). Although 100 pg of noggin is a more potent inducer of neural tissue than $250 \mathrm{pg}$ of $\mathrm{mWnt} 8$, only mWnt8 can repress Bmp4 expression throughout gastrula stages. This experiment suggests that an early Wnt signal, not a BMP antagonist, is responsible for the early

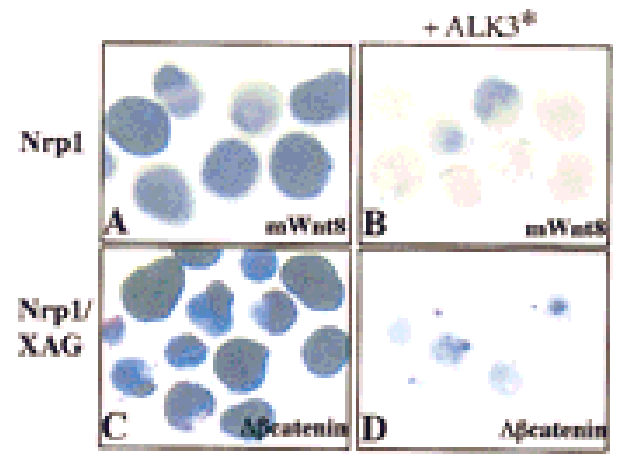

Figure 4. Activated ALK3 inhibits neural induction by $m W n t 8$ and $m \Delta \beta$-catenin. Ectoderm was injected with $100 \mathrm{pg}$ of $m W n t 8$ $(A)$ or $500 \mathrm{pg}$ of $m \Delta \beta$-catenin $(C)$ or coinjected along with $2 \mathrm{ng}$ of constitutively active $A L K 3(B, D)$. Injected ectoderm was aged until stage 20 and probed with either digoxigenin-labeled Nrp1 $(A, B)$ or both digoxigenin-labeled Nrp1 and fluorescein-labeled $X A G(C, D)$. repression of $B m p 4$ from the dorsal side of the embryo and leads us to hypothesize that an early Wnt signal sensitizes the dorsal side of the embryo to respond to neural inducing signals from the organizer.

\section{Is induction of $\beta$-catenin/TCF targets required for neuralization by Wnts?}

Because both of the direct Wnt targets, Xnr3 and siamois, have been shown to have neuralizing activity, we suppressed different aspects of the Wnt response to determine whether neuralization was mediated by these downstream genes. We used the previously characterized reagents $d n X w n t 8$, dominant-negative frizzled 8 (Nxfrz8), and dominant-negative TCF (dnTCF). In Xenopus embryos, $d n T C F$ inhibits both the nuclear localization and axis-inducing properties of $\beta$-catenin (Molenaar et al. 1996). Figure 6 shows ectoderm injected with $m W n t 8$ in combination with either $d n X w n t 8, N x f r z 8$, or $d n T C F$. Ectoderm cultured until gastrula stage (10.5) was analyzed by in situ hybridization for Xnr3 (not shown) or RT-PCR for the expression of $X n r 3$ or siamois, which are both direct targets of Wnt signaling (Fig. 6A). Ectoderm cultured until neurula stage (20) was analyzed by in situ hybridization for the pan-neural marker, Nrp1 (Fig. 6B). As expected, mWnt8 induced both Xnr3 and neural tissue. However, although Nxfrz 8 and dnXwnt 8 could suppress $X n r 3$ and siamois induction by $\mathrm{mWnt} 8$, these reagents did not inhibit the neuralization by mWnt8. Therefore, although $X n r 3$ and siamois may increase the efficiency of neuralization by Wnt signaling, the induction of neural tissue by Wnt8 is at least partially independent of Xnr3 and siamois activity.

In contrast to the effects of $d n X w n t 8$ and Nxfrz8, $d n T C F$ is effective at repressing not only Xnr3 and siamois, but also Nrp1 expression in Wnt8-injected ectoderm. Taken together, therse results suggest that there may be two pathways activated by Wnt signaling that require functional TCF transcription factors to cause neuralization of ectoderm.

\section{Does Wnt signaling affect normal neural development?}

Although Wnt signaling can induce neural tissue in explants, the pathway may or may not be important in normal neural induction. To address this we targeted injections of either $250 \mathrm{pg}$ of $d n T C F$ or $250 \mathrm{pg}$ of $m \Delta \beta$ catenin, with $200 \mathrm{pg}$ of a lacZ tracer, into one of two dorsal blastomeres of the eight-cell Xenopus embryo. At neural-plate stage (14) the embryos were stained for $\beta$-galactosidase activity to identify the cells expressing either dnTCF or $\beta$-catenin (red). The embryos were subsequently analyzed by in situ hybridization (blue) for Nrp1 or muscle actin. Of embryos overexpressing $\beta$-catenin in the neural ectoderm, $72 \%(n=36)$ have a large expansion of neural tissue surrounding the expressing cells (Fig. 7D), consistent with the findings above. $\beta$-Catenin expression within the neural ectoderm does not dramatically affect the differentiation of somites (Fig. 7E), show- 


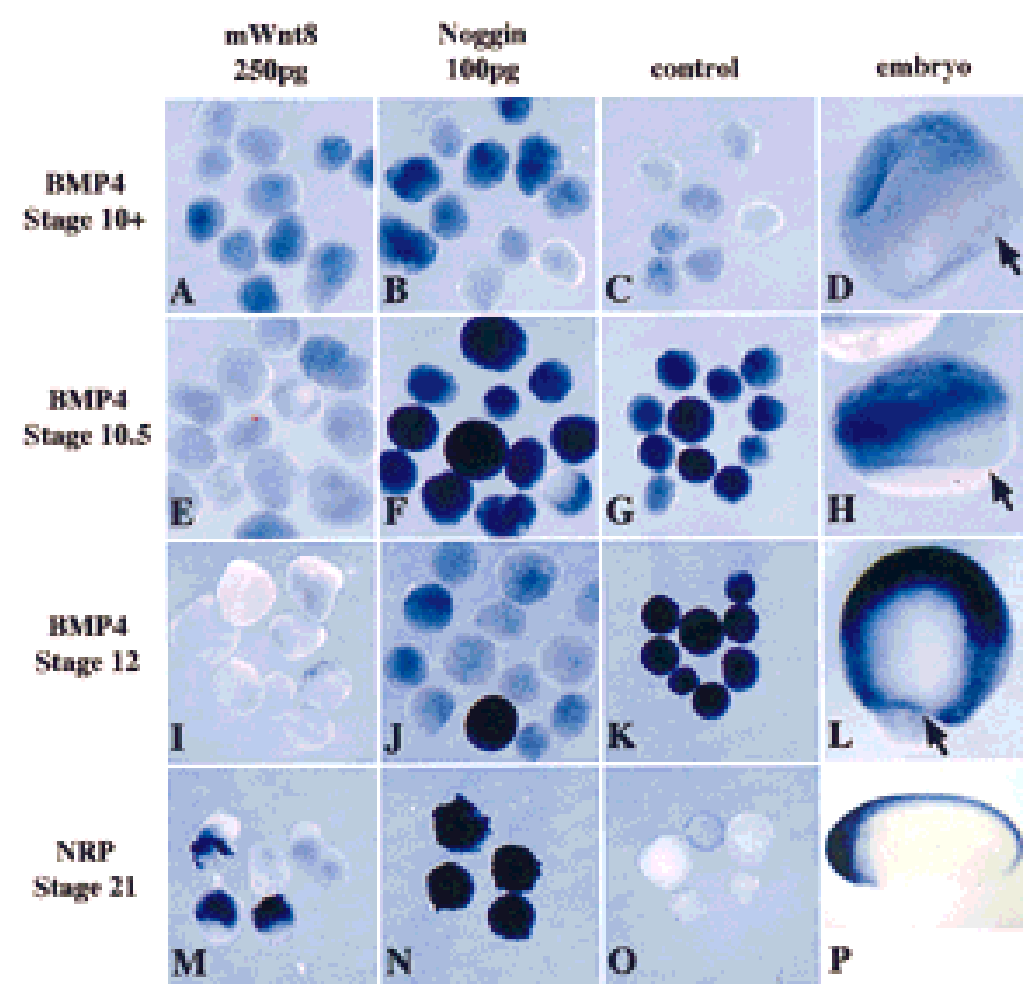

Figure 5. mWnt8, but not Noggin, represses Bmp4 expression during gastrulation. Ectoderm was injected with 250pg of $m W n t 8(A, E, I, M)$ or $100 \mathrm{pg}$ of noggin $(B, F, J, N)$, aged to stage $10(A-C)$, stage 10.5 $(E, F, G)$, stage $12(I-K)$, or stage $21(M-O)$, and probed with either digoxigenin-labeled $B m p 4(A-L)$ or digoxigenin-labeled $\operatorname{Nrp1}(M-P)$. Uninjected ectoderm provides a negative control $(C, G, K, O)$ and whole embryos indicate the normal pattern of expression $(D, H, L, P)$. Arrows in $D, H$ and $L$ indicate the dorsal lip of the blastopore. ing that the effects are likely to be restricted to the ectoderm, rather than being mediated by dorsalized mesoderm. Conversely, when $d n T C F$ is expressed within the neural ectoderm $71 \%(n=21)$ of embryos fail to form neural tissue in and around the $d n T C F$ expressing cells (Fig. 7A,B). dnTCF expression does not affect the developing somites (Fig. 7C). Therefore the inhibition of TCF function in vivo results in abnormal and, in some cases, a complete block to neural development.

\section{Discussion}

\section{Wnt signaling neuralizes ectoderm}

In this paper we describe an unexpected effect of activating the Wnt signaling pathway in prospective ectoderm, namely the robust activation of neural development. Neural tissue was detected with several markers and by both in situ hybridization and RT-PCR. These findings contrast with most previous reports, which did not detect neuralization of ectoderm by Wnts. In some cases we can attribute the differences to the use of markers of neural ectoderm that are not pan-neural (Christian et al. 1992; Otte and Moon 1992). However, we cannot account for other discrepancies (He et al. 1995; LaBonne and Bronner-Fraser 1998).

How would the observation that Wnts inhibit Bmp4 expression and activate neural development fit into a physiological context? There is mounting evidence that cortical rotation activates Wnt signal transduction along most of the dorsal side of the embryo, and this accounts for the elevation of $\beta$-catenin protein levels, which in turn activates $X n r 3$ and siamois expression on the dorsal side of the blastula embryo (Lemaire et al. 1995; Smith et al. 1995; Schneider et al. 1996; Brannon et al. 1997; Larabell et al. 1997; McKendry et al. 1997; Rowning et al. 1997). Nuclear accumulation of $\beta$-catenin has been observed well above the equator and is roughly paralleled by Xnr3 expression (Smith et al. 1995). Accordingly, animal blastomeres from the dorsal side of cleavage-stage embryos show axis inducing activities, which could be accounted for by the redistribution of cortical cytoplasm and the stabilization of $\beta$-catenin in the animal hemisphere (Kageura 1990; Gallagher et al. 1991). The cortical cytoplasm has also been shown to have Wnt-like activity, as in the absence of rotation, Wnt targets are activated near the vegetal pole (Brannon and Kimelman 1996; Darras et al. 1997). In addition, transplantation of vegetal cortex into an animal context occasionally activates neural development, which is consistent with our findings that Wnt signaling can convert ectoderm into neural tissue (Holowacz and Elinson 1995; Kageura 1997). Therefore, it is likely that the activated Wnt signal extends to the animal pole following cortical rotation and thus accounts for the many observations that the dorsal side of the animal cap behaves differently from the ventral side. This was first observed in explants stained for the epidermal antigen, Epi1, which is expressed more strongly on the ventral side of the animal cap ectoderm (London et al. 1988). The dorsal side of the animal cap also shows a dorsal response to mesoderm inducers and enhanced sensitivity to weak neural inducers (Sharpe et al. 1987; Sokol and Melton 1991; Bolce et al. 1992). Previously, it was suggested that increased competence and Epi1 suppression was exclusively the result of organizer 


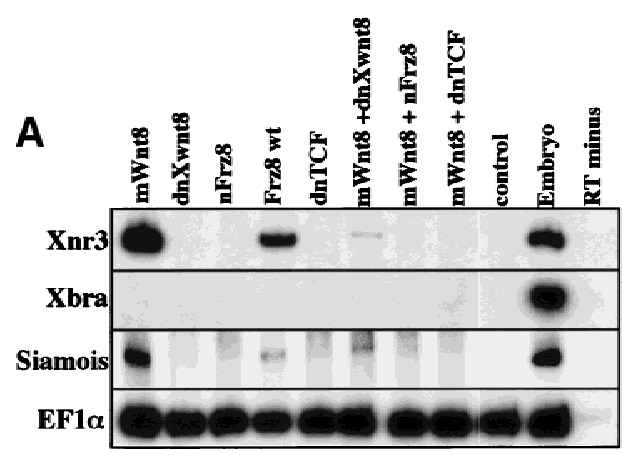

B

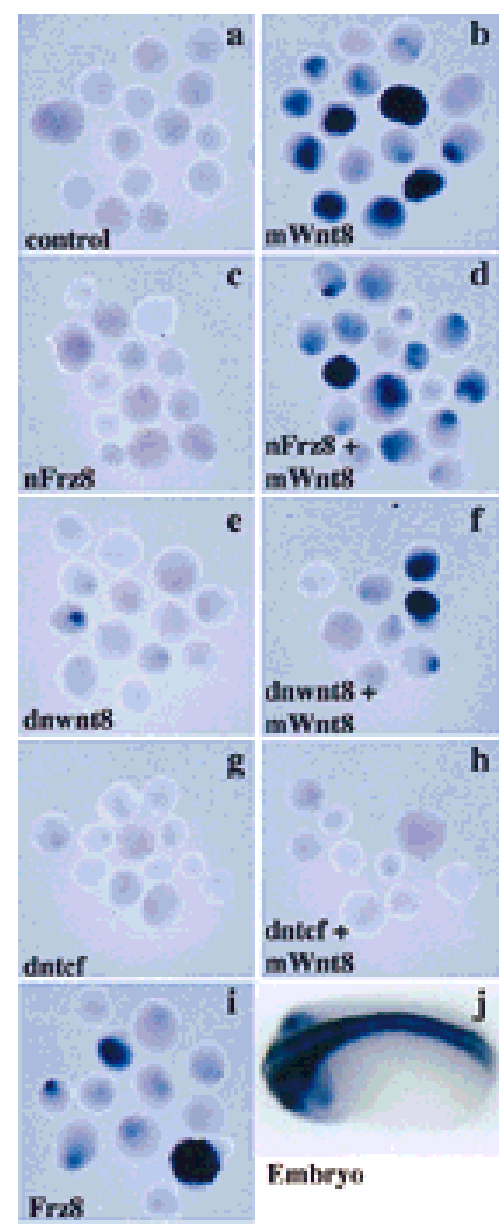

Figure 6. Neuralization without induction of $\beta$-catenin targets. One-cell Xenopus embryos were injected into the animal hemisphere with $250 \mathrm{pg}$ of $m W n t 8,1 \mathrm{ng}$ of $N x f r z 8,500 \mathrm{pg}$ of dnwnt8, $1 \mathrm{ng}$ of $d n t c f, 1 \mathrm{ng}$ of $F r z 8$, or combinations of $250 \mathrm{pg}$ of $m W n t 8$ with either $1 \mathrm{ng}$ of $N x f r z 8,500 \mathrm{pg}$ of $d n w n t 8$, or $1 \mathrm{ng}$ of dntcf. At blastula stage ectoderm was explanted and aged until gastrula or late-neurula stages. Ectoderm aged until gastrula stage (10.5) was analyzed by RT-PCR for Xnr3, Xbra, EF1 $\alpha$ and siamois $(A)$; ectoderm aged until neurula stage $(20)$ was probed with digoxigenin-labeled antisense-Nrp1 by in situ hybridization to detect general neural tissue $(B)$. In $B$, $a$ represents uninjected control ectodermal explants; $j$ is a whole-embryo control.

derived signals (Otte and Moon 1992). However, we suggest that the maternally activated Wnt signal contrib-

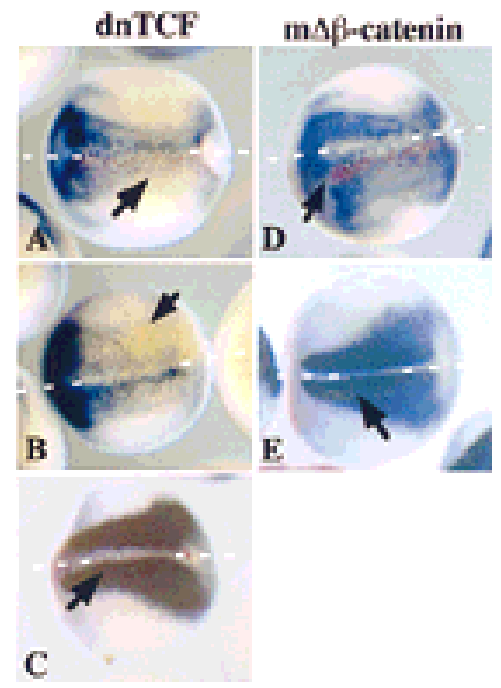

Figure 7. $\beta$-Catenin is necessary for normal neural develop-

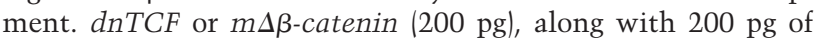
lacZ mRNA, were injected into one of two dorsal blastomeres of eight-cell-staged Xenopus embryos. At neural-plate stage (14), the embryos were stained for the presence of $\beta$-galactosidase activity with Red Gal and subsequently probed with digoxigenin-labeled antisense- $\operatorname{Nrp} 1(A, B, D)$ or digoxigenin-labeled antisense muscle actin $(C, E)$ by in situ hybridization. $A, B$, and $C$ are embryos that have been injected with $\operatorname{dnTCF} ; D$ and $E$ have been injected with $m \Delta \beta$-catenin. Blue indicates the presense of neural tissue $(A, B, D)$ or muscle $(C, E)$; red indicates which cells are expressing the injected proteins. Cells expressing Red Gal were exclusively ectodermal. Arrows point to domains of $\beta$-galactosidase activity. White broken lines delineate the midline in all panels.

utes to the early extinction of $B m p 4$ expression on the dorsal side, extending into the animal hemisphere, and that this extinction could extend beyond the local influence of Wnt targets such as Xnr3 and siamois.

The doses at which Wnt signals can induce neural tissue in the ectoderm are similar to the minimum doses required to induce a complete axis in the mesodermal or endodermal context. Because the latter is thought to mimic physiological levels of activation of the wnt pathway (Heasman et al. 1994), it is reasonable to suppose that the neuralizing doses are in a similar physiological range. Indeed, the neuralizing effect of Wnt pathway activation could account for the relatively normal neural plate found in zebrafish that lack dorsal mesoderm (Feldman et al. 1998)

Previously Wnt $3 a$ in combination with noggin was shown to induce krox-20-expressing cells, which were interpreted to consist of hindbrain or of cephalic neural crest (McGrew et al. 1995; Saint-Jeannet et al. 1997). Although it is possible that the krox-20-expressing cells induced in our assays are cephalic neural crest, the apparently overlapping expression of neural markers suggest that at least some krox-20 reflects the presence of hindbrain. Our results showing that Wnt signaling has potent effects on Bmp4 expression suggest that the ability of Wnts to induce neural crest may in part be a result 
of attenuating BMP signaling in prospective epidermis (LaBonne and Bronner-Fraser 1998; Marchant et al. 1998).

\section{Alternative mechanisms for Wnt signal transduction}

Previous reports have shown that Wnt signaling directly activates the expression of the genes siamois and Xnr3 (Smith et al. 1995; Brannon et al. 1997; McKendry et al. 1997). Both siamois and Xnr3 have been shown to have neuralizing activity when overexpressed in ectoderm by either blocking Bmp4 expression (siamois) or activity (Xnr3) (Carnac et al. 1996; Hansen et al. 1997). Surprisingly, by using dominant-negative signaling molecules, we inhibit the ability of $m W n t 8$ to induce Xnr3 and siamois, but we still see potent neuralizing activity. Therefore, the properties of $d n X w n t 8$ and Nxfrz 8 show that neuralization cannot simply be the result of potent activation of Xnr3 and siamois.

Although Wnt signal transduction was originally viewed as a linear pathway, whereby stimulation of $\beta$-catenin and Lef/Tcf complexes activate downstream target genes, recent evidence suggests that Wnt signal transduction is far more complex, consisting of bifurcations at multiple steps (Bejsovec and Wieschaus 1995; Bhanot et al. 1996; Rocheleau et al. 1997; Slusarski et al. 1997; Axelrod et al. 1998; Boutros et al. 1998; Kengaku et al. 1998; Li et al. 1999). Observations presented here, which show a separation of Xnr3 induction and neural induction, also suggest a bifurcation in Wnt signaling. Wnt 8 can induce both neural markers and $X n r 3$, but only the $X n r 3$ induction is inhibited by dominant-negative molecules (nFrz8 and $d n X w n t 8)$. Indeed, $d n X w n t 8$ is able to induce neural markers on its own at high concentrations. Several models could account for this phenomenon. First, as suggested previously (Bejsovec and Wieschaus 1995), Wnt proteins may act through a single cell-surface receptor, Frizzled, but the conformation of the Wnt ligand bound to the receptor may change the receptor conformation and thus change the receptor's targets. Secondly, a single Wnt may bind multiple receptors and act selectively among these to transduce particular signals. Lastly, Wnt proteins may bind extracellularly to BMPs, as well as signal through their Frizzled receptors. A Wnt extracellular interaction with BMPs would lead to neural induction, whereas signaling through receptors would lead to the classic Wnt-like responses. However, several Wnt transducing components can also induce neural development, showing that BMP binding cannot be the only mechanism of Wnt-mediated neural induction. In addition, if Wnts bound directly to BMPs, they should still be able to neuralize ectoderm when expressed zygotically (Lamb et al. 1993), which we find they do not. Furthermore, if Wnt signaling is inhibited using dnTCF, neural induction is blocked, suggesting that Wnts are triggering neural induction intracellularly. We therefore favor the first or second possibility, that wild-type Wnts activate more than one signal transduction pathway, possibly by activating several receptors, both of these pathways involving the TCF class of transcription factors. Thus, although dnXwnt8 and Nxfrz8 may act as antagonists for the receptor that normally induces Xnr3 expression, they do not antagonize the receptor that provides neural-inducing signals. Activation of this second pathway would result in the suppression of $B m p 4$ expression without the activation of Xnr3.

\section{Materials and methods}

e6.5 and e7.5 cDNA library construction

e6.5 mouse embryos (178) and 281 e7.5 mouse embryos were dissected in M16 medium containing 10\% FBS (Hogan et al. 1994). Embryonic and extraembryonic tissues were maintained in e6.5 embryos, whereas extraembryonic tissues were removed in e7.5 embryos. The embryos were homogenized using $4 \mathrm{M}$ guanadinium isothiocyanate and total RNA isolated using acid phenol extraction (Chomczynski and Sacchi 1987). Total RNA from e7.5 (80 $\mu \mathrm{g})$ and e6.5 (30 $\mu \mathrm{g})$ embryos, respectively, was used to generate cDNA using the Superscript plasmid system (GIBCO-BRL). cDNA from either e7.5 or e6.5 embryos was cloned unidirectionally into a modified $\mathrm{pCS}^{+}$vector, pCS105 (Turner and Weintraub 1994; Hsu et al. 1998). XL1Blue electrocompetent cells (Stratagene) were transformed with ligated cDNAs. Each of the resulting libraries has $>500,000$ clones and has average cDNA insert sizes of $1.7 \mathrm{~kb}$, as judged by analysis of 20 randomly picked clones from each library.

\section{Expression cloning}

Both the e6.5 and the e7.5 libraries were plated into 50 pools each containing 200 colonies (Baker and Harland 1996). Plasmid DNA was isolated by alkaline lysis and Qiagen Mini-Prep Columns. Pooled plasmid DNA was linearized with AscI and transcribed into capped mRNA with SP6 RNA polymerase using Ambion mMessage mMachine. Ten nanoliters of $1 \mathrm{mg} / \mathrm{ml}$ mRNA (10 ng) was introduced at the animal pole of the one-cell Xenopus embryo. Animal cap ectoderm was explanted at blastula stage (8-9) and aged to either gastrula stage (10.5) or lateneurula stage (20-24). RNA from ectoderm was isolated and subsequently digested with DNase to remove genomic DNA prior to RT-PCR (Wilson and Melton 1994). Primer sets for analysis of Xbra, NCAM, Krox-20, EF1 $\alpha$ and Hoxb9 were described by Hemmati-Brivanlou and Melton (1994). Primer sets for analysis of Nrp1 are as described (Lamb and Harland 1995). Xnr3 primers are as follows: U-AGGCAAAAGGTCTCCATC and D-CCGATCTTCTGAAAGTCC.

\section{In situ hybridization}

Mouse embryos Whole-mount in situ hybridization on mouse embryos used the protocol described (Belo et al. 1997). mWnt3 and $\mathrm{mWnt} 8$ were subcloned into the expression vector pCS107, a modified version of pCS105, in which the T7 promotor is functional. pCS107 containing mWnt3 and mWnt8 (pCS7mWnt3 and pCS7mWnt8) were linearized with HindIII and transcribed using T7 RNA polymerase, which generates an anti-sense probe for in situ hybridization. Color was developed using NBT/BCIP (Biosynth AG) as the alkaline phosphatase substrate.

Xenopus embryos Xenopus embryos were stained by in situ hybridization as described (Harland 1991; Knecht et al. 1995). For double-labeled in situ hybridizations, a dioxygenin-labeled antisense Nrp1 probe and fluorescein-conjugated-antisense $X A G$ probe were hybridized simultaneously. After hybridization anti-dioxygenin-AP-Fab (1/2000, Boehringer Mannheim) 
was used and color developed using the substrate BM Purple (Boehringer Mannheim). After signal reached desired levels, the phosphatase activity was quenched with $10 \mathrm{~mm}$ EDTA for 10 min at $60^{\circ} \mathrm{C}$. Subsequently, samples were incubated with antifluorescein-AP-Fab (1/10,000, Boehringer Mannheim) and developed using MagentaPhos (Biosynth AG) alkaline phosphatase substrate. Templates for the production of Xnr3 (Smith et al. 1995), Nrp1 (Knecht et al. 1995), Xag-1 (Sive et al. 1989), Krox-20 (Bradley et al. 1993), Bmp4 (Hemmati-Brivanlou and Thomsen 1995), and muscle actin (Hemmati-Brivanlou et al. 1990) in situ hybridization probes have been described previously.

$\beta$-Galactosidase protein was visualized as described by Smith and Harland (1991) with the modification that 6-chloro-3-indolyl- $\beta$-D-galactoside (Red Gal, Research Organics, Inc.) was used in place of X-gal. Following staining, embryos were refixed and whole-mount in situ hybridizations were carried out according to the method of Harland (1991) with the modifications described by Knecht et al. (1995).

\section{Plasmids and mRNA}

Plasmids used in this work include SP64T Xwnt8 (Christian and Moon 1993), CS107 mWnt8 (this paper), CS107 mWnt3 (this paper), CS105 $\mathrm{m} \Delta$ ßcatenin (this paper), XE47 (dnXwnt8, Hoppler et al. 1996), Xdsh-pSP64T (Sokol et al. 1995), XG114 (dnGSK3, Yost et al. 1998), xfrz8/pCS2 and Nxfrz8/pCS2 (Deardorff et al. 1998), pCS hfrz5mut (J. Xie, UCSF), pCS hfrz5 (J. Xie), pXwnt5a-SP64T (Moon et al. 1993), BMPR/Q233D-pCS2 (Hsu et al. 1998), and XE60, which we refer to throughout the text as dnTCF ( $\triangle$ NXTcf-3, Molenaar et al. 1996). Synthetic capped mRNA was made by linearizing these plasmids at the 3 ' end and subsequently transcribing with SP6 RNA polymerase with Ambion mMessage mMachine. To test for possible neuralizing effects of Wnts expressed at blastula stages, CS107 mWnt8 and CS107 mWnt3 were injected into ectoderm as DNA at concentrations of 500 and $200 \mathrm{pg}$. CS107 contains a CMV promoter, which is activated post-MBT.

\section{Acknowledgments}

We are grateful to David Kimelman, Randy Moon, Sergei Sokol, Jingwu Xie, Frank McCormick, and Peter Klein for providing us with plasmids. Thanks are due to John Wallingford, Brian Rowning, and Francesca Mariani for advice on this manuscript and for valuable discussions. We are most grateful to the Harland laboratory, John Gerhart, David Hsu, and Tim Grammer for useful discussions throughout the course of this work. This investigation has been aided by a postdoctoral grant from the Jane Coffin Childs Memorial Fund for Medical Research to J.C.B. This work was supported by National Institutes of Health grant GM42341 (R.M.H.) and the University of California Miller Foundation (R.S.P.B.).

The publication costs of this article were defrayed in part by payment of page charges. This article must therefore be hereby marked "advertisement" in accordance with 18 USC section 1734 solely to indicate this fact.

\section{References}

Axelrod, J.D., J.R. Miller, J.M. Shulman, R.T. Moon, and N. Perrimon. 1998. Differential recruitment of Dishevelled provides signaling specificity in the planar cell polarity and Wingless signaling pathways. Genes \& Dev. 12: 2610-2622.

Baker, J.C. and R.M. Harland. 1996. A novel mesoderm inducer, Madr2, functions in the activin signal transduction pathway. Genes \& Dev. 10: 1880-1889.

Bejovec, A. and E. Wieschaus. 1995. Signaling activities of the
Drosophila wingless gene are separately mutable and appear to be transduced at the cell surface. Genetics 139: 309-320.

Belo, J.A., T. Bouwmeester, L. Leyns, N. Kertesz, M. Gallo, M. Follettie, and E.M. De Robertis. 1997. Cerberus-like is a secreted factor with neutralizing activity expressed in the anterior primitive endoderm of the mouse gastrula. Mech. Dev. 68: $45-57$.

Bhanot, P., M. Brink, C.H. Samos, J.C. Hsieh, Y. Wang, J.P. Macke, D. Andrew, J. Nathans, and R. Nusse. 1996. A new member of the frizzled family from Drosophila functions as a Wingless receptor. Nature 382: 225-230.

Bolce, M.E., A. Hemmati-Brivanlou, P.D. Kushner, and R.M. Harland. 1992. Ventral ectoderm of Xenopus forms neural tissue, including hindbrain, in response to activin. Development 115: 681-688.

Bouillet, P., M. Oulad-Abdelghani, S.J. Ward, S. Bronner, P. Chambon, and P. Dolle. 1996. A new mouse member of the Wnt gene family, mWnt-8, is expressed during early embryogenesis and is ectopically induced by retinoic acid. Mech. Dev. 58: 141-152.

Boutros, M., N. Paricio, D.I. Strutt, and M. Mlodzik. 1998. Dishevelled activates JNK and discriminates between JNK pathways in planar polarity and wingless signaling. Cell 94: 109-118.

Bouwmeester, T., S. Kim, Y. Sasai, B. Lu, and E.M. De Robertis. 1996. Cerberus is a head-inducing secreted factor expressed in the anterior endoderm of Spemann's organizer. Nature 382: 595-601.

Bradley, L.C., A. Snape, S. Bhatt, and D.G. Wilkinson. 1993. The structure and expression of the Xenopus Krox-20 gene: Conserved and divergent patterns of expression in rhombomeres and neural crest. Mech. Dev. 40: 73-84.

Brannon, M. and D. Kimelman. 1996. Activation of Siamois by the Wnt pathway. Dev. Biol. 180: 344-347.

Brannon, M., M. Gomperts, L. Sumoy, R.T. Moon, and D. Kimelman. 1997. A beta-catenin/XTcf-3 complex binds to the siamois promoter to regulate dorsal axis specification in Xenopus. Genes \& Dev. 11: 2359-2370.

Carnac, G., L. Kodjabachian, J.B. Gurdon, and P. Lemaire. 1996. The homeobox gene Siamois is a target of the Wnt dorsalisation pathway and triggers organiser activity in the absence of mesoderm. Development 122: 3055-3065.

Chomczynski, P. and N. Sacchi. 1987. Single-step method of RNA isolation by acid guanidinium thiocyanate-phenolchloroform extraction. Anal. Biochem. 162: 156-159.

Christian, J.L. and R.T. Moon. 1993. Interactions between Xwnt-8 and Spemann organizer signaling pathways generate dorsoventral pattern in the embryonic mesoderm of Xenopus. Genes \& Dev. 7: 13-28.

Christian, J.L., D.J. Olson, and R.T. Moon. 1992. Xwnt-8 modifies the character of mesoderm induced by bFGF in isolated Xenopus ectoderm. EMBO J. 11: 33-41.

Darras, S., Y. Marikawa, R.P. Elinson, and P. Lemaire. 1997. Animal and vegetal pole cells of early Xenopus embryos respond differently to maternal dorsal determinants: Implications for the patterning of the organiser. Development 124: $4275-4286$.

Deardorff, M.A., C. Tan, L.J. Conrad, and P.S. Klein. 1998. Frizzled-8 is expressed in the Spemann organizer and plays a role in early morphogenesis. Development 125: 2687-2700.

Dominguez, I., K. Itoh, and S.Y. Sokol. 1995. Role of glycogen synthase kinase 3 beta as a negative regulator of dorsoventral axis formation in Xenopus embryos. Proc. Natl. Acad. Sci. 92: 8498-8502.

Fainsod, A., H. Steinbeisser, and E.M. De Robertis. 1994. On the function of BMP-4 in patterning the marginal zone of the 
Xenopus embryo. EMBO J. 13: 5015-5025.

Fainsod, A., K. Deissler, R. Yelin, K. Marom, M. Epstein, G. Pillemer, H. Steinbeisser, and M. Blum. 1997. The dorsalizing and neural inducing gene Follistatin is an antagonist of BMP-4. Mech. Dev. 63: 39-50.

Feldman, B., M.A. Gates, E.S. Egan, S.T. Dougan, G. Rennebeck, H.I. Sirotkin, A.F. Schier, and W.S. Talbot. 1998. Zebrafish organizer development and germ-layer formation require nodal-related signals. Nature 395: 181-185.

Gallagher, B.C., A.M. Hainski, and S.A. Moody. 1991. Autonomous differentiation of dorsal axial structures from an animal cap cleavage stage blastomere. Development 112: 1103-1114.

Glinka, A., W. Wu, D. Onichtchouk, C. Blumenstock, and C. Niehrs. 1997. Head induction by simultaneous repression of Bmp and Wnt signalling in Xenopus. Nature 389: 517-519.

Hammerschmidt, M., G.N. Serbedzija, and A.P. McMahon. 1996. Genetic analysis of dorsoventral pattern formation in the zebrafish: Requirement of a BMP-like ventralizing activity and its dorsal repressor. Genes \& Dev. 10: 2452-2461.

Hansen, C.S., C.D. Marion, K. Steele, S. George, and W.C. Smith. 1997. Direct neural induction and selective inhibition of mesoderm and epidermis inducers by Xnr3. Development 124: 483-492.

Harland, R.M. 1991. In situ hybridization: An improved whole mount method for Xenopus embryos. In Methods in cell biology (ed. B.K. Kay and H.B. Perg) pp. 675-685. Academic Press; San Diego, CA.

. 1997. Neural induction in Xenopus. In Molecular and cellular approaches to neural development, (ed. W.M. Cowan, T.M. Jessell, and S.L. Zipurskyl, pp. 1-25. Oxford University Press; New York, NY.

He, X., J.-P. Saint-Jeannet, J.R. Woodgett, H.E. Varmus, and I.B. Dawid. 1995. Glycogen synthase kinase-3 and dorsoventral patterning in Xenopus embryos. Nature 374: 617-622.

He, X., J.P. Saint-Jeannet, Y. Wang, J. Nathans, I. Dawid, and H. Varmus. 1997. A member of the Frizzled protein family mediating axis induction by Wnt-5A. Science 275: 1652-1654.

Heasman, J., A. Crawford, K. Goldstone, P. Garner-Hamrick, B. Gumbiner, P. McCrea, C. Kintner, C.Y. Noro, and C. Wylie. 1994. Overexpression of cadherins and underexpression of beta-catenin inhibit dorsal mesoderm induction in early Xenopus embryos. Cell 79: 791-803.

Hemmati-Brivanlou, A. and D.A. Melton. 1994. Inhibition of activin receptor signalling promotes neuralization in $\mathrm{X}$. laevis. Cell 77: 273-281.

Hemmati-Brivanlou, A. and G.H. Thomsen. 1995. Ventral mesodermal patterning in Xenopus embryos: Expression patterns and activities of BMP-2 and BMP-4. Dev. Genet. 17: 78-89.

Hemmati-Brivanlou, A., D. Frank, M.E. Bolce, B.D. Brown, H.L. Sive, and R.M. Harland. 1990. Localization of specific mRNAs in Xenopus embryos by whole-mount in situ hybridization. Development 110: 325-330.

Hemmati-Brivanlou, A., O.G. Kelly, and D.A. Melton. 1994. Follistatin, an antagonist of activin, is expressed in the Spemann organizer and displays direct neuralizing activity. Cell 77: 283-295.

Hogan, B., R. Beddington, F. Costantini, and E. Lacy. 1994. Manipulating the mouse embryo: A laboratory manual 2nd ed. Cold Spring Harbor Laboratory Press, Cold Spring Harbor, NY.

Holowacz, T. and R.P. Elinson. 1995. Properties of the dorsal activity found in the vegetal cortical cytoplasm of Xenopus eggs. Development 121: 2789-2798.

Hoppler, S., J.D. Brown, and R.T. Moon. 1996. Expression of a dominant-negative Wnt blocks induction of MyoD in Xenopus embryos. Genes \& Dev. 10: 2805-2817.

Hsu, D.R., A.N. Economides, X. Wang, P.M. Eimon, and R.M. Harland. 1998. The Xenopus dorsalizing factor gremlin identifies a novel family of secreted proteins that antagonize BMP activities. Mol. Cell 1: 673-683.

Jones, C.M., K.M. Lyons, P.M. Lapan, C.V. Wright, and B.L. Hogan. 1992. DVR-4 (bone morphogenetic protein-4) as a posterior-ventralizing factor in Xenopus mesoderm induction. Development 115: 639-647.

Kageura, H. 1990. Spatial distribution of the capacity to initiate a second embryo in the 32-cell embryos of Xenopus laevis. Dev. Biol. 142: 432-438.

1997. Activation of dorsal development by contact between the cortical dorsal determinant and the equatorial core cytoplasm in eggs of Xenopus laevis. Development 124: $1543-1551$.

Kengaku, M., J. Capdevila, C. Rodriguez-Esteban, J. De La Pena, R.L. Johnson, J. Carlos Izpisua Belmonte, and C.J. Tabin. 1998. Distinct WNT pathways regulating AER formation and dorsoventral polarity in the chick limb bud. Nature 280: $1274-1277$.

Knecht, A.K., P.J. Good, I.B. Dawid, and R.M. Harland. 1995. Dorsal-ventral patterning and differentiation of noggin-induced neural tissue in the absence of mesoderm. Development 121: 1927-1935.

LaBonne, C. and M. Bronner-Fraser. 1998. Neural crest induction in Xenopus: Evidence for a two-signal model. Development 125: 2403-2414.

Lamb, T.M. and R.M. Harland. 1995. Fibroblast growth factor is a direct neural inducer, which combined with noggin generates anterior-posterior neural pattern. Development 121: 3627-3636.

Lamb, T.M., A.K. Knecht, W.C. Smith, S.E. Stachel, A.N. Economides, N. Stahl, G.D. Yancopolous, and R.M. Harland. 1993. Neural induction by the secreted polypeptide noggin. Science 262: 713-718.

Larabell, C.A., M. Torres, B.A. Rowning, C. Yost, J.R. Miller, M. Wu, D. Kimelman, and R.T. Moon. 1997. Establishment of the dorso-ventral axis in Xenopus is presaged by early asymmetries in beta-catenin that are modulated by the Wnt signaling pathway. J. Cell Biol. 136: 1123-1136.

Lemaire, P., N. Garrett, and J.B. Gurdon. 1995. Expression cloning of siamois, a Xenopus homeobox gene expressed in dorsal-vegetal cells of blastulae and able to induce a complete secondary axis. Cell 81: 85-94.

Leyns, L., T. Bouwmeester, S.H. Kim, S. Piccolo, and E.M. De Robertis. 1997. Frzb-1 is a secreted antagonist of Wnt signaling expressed in the Spemann organizer. Cell 88: 747-756.

Li, L., H. Yuan, W. Xie, J. Mao, A.M. Caruso, A. McMahon, D.J. Sussman, and D. Wu. 1999. Dishevelled proteins lead to two signaling pathways. Regulation of LEF-1 and c-Jun N-terminal kinase in mammalian cells. J. Biol. Chem. 274: 129-134.

London, C., R. Akers, and Phillips. C. 1988. Expression of Epi 1, an epidermis-specific marker in Xenopus laevis embryos, is specified prior to gastrulation. Dev. Biol. 129:380-389.

Maniatis, T. 1999. A ubiquitin ligase complex essential for the NF-кB, Wnt/Wingless, and Hedgehog signaling pathways. Genes \& Dev. 13: 505-509.

Marchant, L., C. Linker, P. Ruiz, N. Guerrero, and R. Mayor. 1998. The inductive properties of mesoderm suggest that the neural crest cells are specified by a BMP gradient. Dev. Biol. 198: 319-329.

McGrew, L.L., C.J. Lai, and R.T. Moon. 1995. Specification of the anteroposterior neural axis through synergistic interaction of the Wnt signaling cascade with noggin and follistatin. 
Dev. Biol. 172: 337-342.

McGrew, L.L., S. Hoppler, and R.T. Moon. 1997. Wnt and FGF pathways cooperatively pattern anteroposterior neural ectoderm in Xenopus. Mech. Dev. 69: 105-114.

McKendry, R., S.C. Hsu, R.M. Harland, and R. Grosschedl. 1997. LEF-1/TCF proteins mediate wnt-inducible transcription from the Xenopus nodal-related 3 promoter. Dev. Biol. 192: 420-431.

Molenaar, M., M. van de Wetering, M. Oosterwegel, J. PetersonMaduro, S. Godsave, V. Korinek, J. Roose, O. Destree, and H. Clevers. 1996. Xtcf-3 transcription factor mediates $\beta$-catenin-induced axis formation in Xenopus embryos. Cell 86: 391-399.

Moon, R.T. R.M. Campbell, J.L. Christian, L.L. McGrew, J. Shih, and S. Fraser. 1993. Xwnt-5A: A maternal Wnt that affects morphogenetic movements after overexpression in embryos of Xenopus laevis. Development 119: 97-111.

Nguyen, V.H., B. Schmid, J. Trout, S.A. Connors, M. Ekker, and M.C. Mullins. 1998. Ventral and lateral regions of the zebrafish gastrula, including the neural crest progenitors, are established by a bmp2b/swirl pathway of genes. Dev. Biol. 199: 93-110.

Otte, A.P. and R.T. Moon. 1992. Ectopic induction of dorsal mesoderm by overexpression of Xwnt- 8 elevates the neural competence of Xenopus ectoderm. Dev. Biol. 152: 184-187.

Piccolo, S., Y. Sasai, B. Lu, and E.M. De Robertis. 1996. Dorsoventral patterning in Xenopus: Inhibition of ventral signals by direct binding of chordin to BMP-4. Cell 86: 589-598.

Piccolo, S., E. Agius, B. Lu, S. Goodman, L. Dale, and E.M. De Robertis. 1997. Cleavage of Chordin by Xolloid metalloprotease suggests a role for proteolytic processing in the regulation of Spemann organizer activity. Cell 91: 407-416.

Pierce, S.B. and D. Kimelman. 1995. Regulation of Spemann organizer formation by the intracellular kinase Xgsk-3. Development 121: 755-765.

Rocheleau, C.E., W.D. Downs, R. Lin, C. Wittmann, Y. Bei, Y.H. Cha, M. Ali, J.R. Priess, and C.C. Mello. 1997. Wnt signaling and an APC-related gene specify endoderm in early C. elegans embryos. Cell 90: 707-716.

Rowning, B.A., J. Wells, M. Wu, J.C. Gerhart, R.T. Moon, and C.A. Larabell. 1997. Microtubule-mediated transport of organelles and localization of beta-catenin to the future dorsal side of Xenopus eggs. Proc. Nat1. Acad. Sci. 94: 1224-1229.

Saint-Jeannet, J.P., X. He, H.E. Varmus, and I.B. Dawid. 1997. Regulation of dorsal fate in the neuraxis by Wnt-1 and Wnt3a. Proc. Nat1. Acad. Sci. 94: 13713-13718.

Sasai, Y., B. Lu, H. Steinbeisser, D. Geissert, L.K. Gont, and E.M. De Robertis. 1994. Xenopus chordin: A novel dorsalizing factor activated by organizer-specific homeobox genes. Cell 79: 779-790.

Sasai, Y., B. Lu, H. Steinbeisser, and E.M. De Robertis. 1995. Regulation of neural induction by the Chd and Bmp-4 antagonistic patterning signals in Xenopus. Nature 376: 333 336.

Schneider, S., H. Steinbeisser, R.M. Warga, and P. Hausen. 1996. Beta-catenin translocation into nuclei demarcates the dorsalizing centers in frog and fish embryos. Mech. Dev. 57: 191-198.

Sharpe, C.R., A. Fritz, R.E. De, and J.B. Gurdon. 1987. A homeobox-containing marker of posterior neural differentiation shows the importance of predetermination in neural induction. Cell 50: 749-758.

Siegfried, E., T.B. Chou, and N. Perrimon. 1992. wingless signaling acts through zeste-white 3, the Drosophila homolog of glycogen synthase kinase-3, to regulate engrailed and establish cell fate. Cell 71: 1167-1179.
Sive, H.L., K. Hattori, and H. Weintraub. 1989. Progressive determination during formation of the anteroposterior axis in Xenopus laevis. Cell 58: 171-180.

Slusarski, D.C., V.G. Corces, and R.T. Moon. 1997. Interaction of Wnt and a Frizzled homologue triggers G-protein-linked phosphatidylinositol signalling. Nature 390: 410-413.

Smith, W.C. and R.M. Harland. 1991. Injected Xwnt-8 RNA acts early in Xenopus embryos to promote formation of a vegetal dorsalizing center. Cell 67: 753-765.

. 1992. Expression cloning of noggin, a new dorsalizing factor localized to the Spemann organizer in Xenopus embryos. Cell 70: 829-840.

Smith, W.C., A.K. Knecht, M. Wu, and R.M. Harland. 1993. Secreted noggin protein mimics the Spemann organizer in dorsalizing Xenopus mesoderm. Nature 361: 547-549.

Smith, W.C., R. McKendry, S. Ribisi, and R.M. Harland. 1995. A nodal-related gene defines a physical and functional domain within the Spemann organizer. Cell 82: 37-46.

Sokol, S.Y. 1996. Analysis of dishevelled signalling pathways during Xenopus development. Curr. Biol. 6: 1456-1467.

Sokol, S. and D.A. Melton. 1991. Pre-existent pattern in Xenopus animal pole cells revealed by induction with activin. Nature 351: 409-411.

Sokol, S.Y., J. Klingensmith, N. Perrimon, and K. Itoh. 1995. Dorsalizing and neuralizing properties of Xdsh, a maternally expressed Xenopus homolog of dishevelled. Development 121: $1637-1647$.

Streit, A., K.J. Lee, I. Woo, C. Roberts, T.M. Jessell, and C.D. Stern. 1998. Chordin regulates primitive streak development and the stability of induced neural cells, but is not sufficient for neural induction in the chick embryo. Development 125: 507-519.

Turner, D.L. and H. Weintraub. 1994. Expression of achaetescute homolog 3 in Xenopus embryos converts ectodermal cells to a neural fate. Genes \& Dev. 8: 1434-1447.

Vleminckx, K., E. Wong, K. Guger, B. Rubinfield, P. Polakis, and B.M. Gumbiner. 1997. Adenomatous polyposis coli tumor suppressor protein has signaling activity in Xenopus laevis embryos resulting in the induction of an ectopic dorsoanterior axis. J. Cell Biol. 136: 411-420.

Wang, S., M. Krinks, K. Lin, F.P. Luyten, and M. Moos, Jr. 1997. Frzb, a secreted protein expressed in the Spemann organizer, binds and inhibits Wnt-8. Cell 88: 757-766.

Willert, K. and R. Nusse. 1998. Beta-catenin: A key mediator of Wnt signaling. Curr. Opin. Genet. Dev. 8: 95-102.

Wilson, P.A. and D.A. Melton. 1994. Mesodermal patterning by an inducer gradient depends on secondary cell-cell communication. Curr. Biol. 4: 676-686.

Yanagawa, S., F. van Leeuwen, A. Wodarz, J. Klingensmith, and R. Nusse. 1995. The dishevelled protein is modified by wingless signaling in Drosophila. Genes \& Dev. 9: 1087-1097.

Yang-Snyder, J., J.R. Miller, J.D. Brown, C.J. Lai, and R.T. Moon. 1996. A frizzled homolog functions in a vertebrate Wnt signaling pathway. Curr. Biol. 6: 1302-1306.

Yost, C., M. Torres, J.R. Miller, E. Huang, D. Kimelman, and R.T. Moon. 1996. The axis-inducing activity, stability, and subcellular distribution of beta-catenin is regulated in Xenopus embryos by glycogen synthase kinase 3. Genes \& Dev. 10: $1443-1454$.

Yost, C., G.H. Farr III, S.B. Pierce, D.M. Ferkey, M.M. Chen, and D. Kimelman. 1998. GBP, an inhibitor of GSK-3, is implicated in Xenopus development and oncogenesis. Cell 93: 1031-1041.

Zimmerman, L.B., J.M. De Jesus-Escobar, and R.M. Harland. 1996. The Spemann organizer signal noggin binds and inactivates bone morphogenetic protein 4. Cell 86: 599-606. 


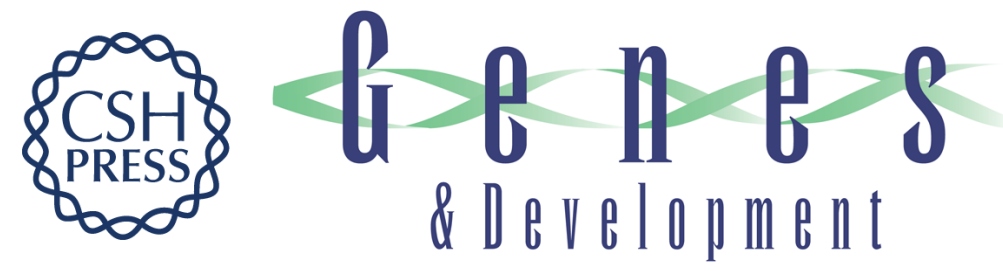

\section{Wnt signaling in Xenopus embryos inhibits Bmp4 expression and activates neural development}

Julie C. Baker, Rosa S.P. Beddington and Richard M. Harland

Genes Dev. 1999, 13:

References This article cites 89 articles, 36 of which can be accessed free at:

http://genesdev.cshlp.org/content/13/23/3149.full.html\#ref-list-1

License

Email Alerting

Service

Receive free email alerts when new articles cite this article - sign up in the box at the top right corner of the article or click here.

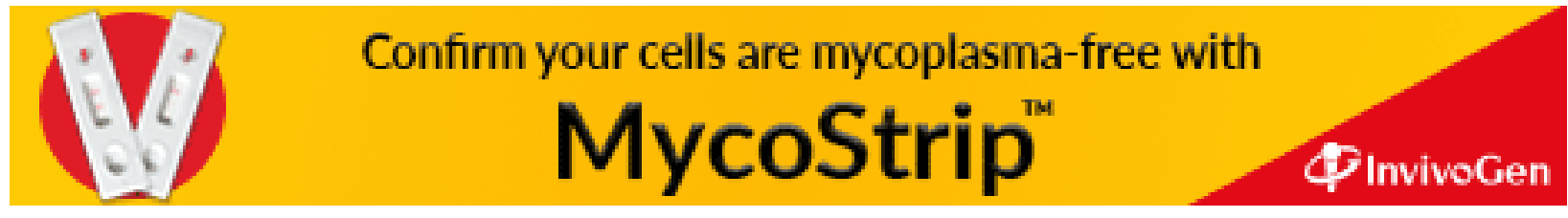

